\title{
Holocene coastal changes and infilling of the La Perroche marsh (French Atlantic coast)
}

\author{
Bérengère CLAVÉ*, Laurent MASSÉ, Pierre CARBONEL, Jean-Pierre TASTET \\ DGO, UMR 5805 CNRS, université Bordeaux-I, avenue des Facultés, 33405 Talence cedex, France
}

Received 4 May 2001; revised and accepted 3 July 2001

\begin{abstract}
The La Perroche marsh is a small Holocene marsh on the south-western coast of the Oleron island (Bay of Biscay, France) presently occupied by a freshwater swamp and separated from the ocean by a continuous sand dune ridge. The study of its infill shows first basal conglomeratic deposits with calcareous pebbles on a Cenomanian rough substrate. The Holocene infill since 6000 years BP begins with a very fast sedimentation of sands. Then, the sedimentation becomes finer, with lagoonal to freshwater influences recorded by ostracods. The distribution of these deposits inside the marsh is asymmetric, with a thick sandy-gravely layer in the eastern part and a succession of sands, clays and organic layers in the western part. Communication with the sea is episodic, and the sedimentation is controlled by an active channel, as shown by the presence of displaced coastal-marine faunas at some sites. Around 5000 years BP, a coastal marsh began to develop with high organic matter contents. These organic deposits presently outcrop on the beach, suggesting a more seaward location of the shoreline at that time. Generally, these sediments are azoic. When fauna is present, it indicates brackish to freshwater environments showing a progressive isolation of the system. A second phase of terrigenous sedimentation occurred after a transgressive event around 2800-2500 years BP, but the communication with the sea was then very reduced, as indicated by mainly freshwater faunas. This transgressive event appears to be synchronous with a positive sea-level tendency recorded, throughout north-western European coasts, between 3000 and 2000 years BP. The definitive closing of the marsh occurred around 2100 years BP, after a second phase of freshwater marsh. (c) 2001 Ifremer/CNRS/IRD/Éditions scientifiques et médicales Elsevier SAS
\end{abstract}

Résumé - Changements côtiers datant de l'Holocène et comblements du marais de La Perroche (côte atlantique française). Le marais holocène de La Perroche, localisé sur la côte sud-ouest de l'île d'Oléron (golfe de Gascogne, France), est actuellement un marais d'eau douce séparé du domaine océanique par un cordon dunaire continu. L'étude de son comblement au cours des 6000 dernières années montre d'abord une invasion marine sur un substrat très accidenté d'âge cénomanien. Ensuite, se déposent probablement rapidement des sédiments sableux, témoins à la fois de l'établissement et du démantèlement de cordons dunaires et de l'érosion de l'arrière pays. Puis, la sédimentation devient plus fine et de type laguno-lacustre ainsi que le montrent les faunes d'ostracodes souvent associées aux sédiments. La distribution des dépôts dans le marais apparaît dés le début dissymétrique avec la présence d'épais niveaux sablo-graveleux à l'est et des successions de sables, d'argiles et de dépôts organiques à l'ouest. Les communications avec la mer sont épisodiques et le dépôt des sédiments est commandé par une chenalisation très active. Celle-ci est soulignée par la présence à proximité immédiate du chenal de faunes de type marin, le plus souvent déplacées et amenées en suspension. Vers 5000 ans BP s'installe un marais côtier, très riche en matière organique le plus souvent dépourvu de faune. Lorsque la faune est présente, elle indique des milieux laguno-saumâtres ou lacustres, confirmant ainsi l'isolation progressive du système. Des dépôts tourbeux trouvés sur la plage sont contemporains de ceux du marais actuel, ce qui implique une continuité sédimentaire entre ces deux sites et donc une situation des cordons dunaires plus au large qu'actuellement. Une seconde phase de sédimentation apparaît à la suite d'un événement transgressif vers

* Correspondence and reprints.

E-mail address: b.clave@geocean.u-bordeaux.fr (B. CLAVÉ).

(C) 2001 Ifremer/CNRS/IRD/Éditions scientifiques et médicales Elsevier SAS. Tous droits réservés

S0399178401011537/FLA 
2800-2500 ans BP mais les communications avec le milieu marin sont très réduites comme le montrent les faunes majoritairement d'eaux douces. Cet épisode transgressif apparaît synchrone avec une tendance positive générale du niveau des eaux enregistrée entre 3000 et 2000 ans BP le long des côtes de l'Europe du nord-ouest. La fermeture définitive du marais intervient plus tard, après une seconde phase de développement de marécages vers 2100 ans BP. (C) 2001 Ifremer/CNRS/IRD/Éditions scientifiques et médicales Elsevier SAS

\section{coastal changes / coastal salt marsh / Holocene / ostracods / sediments}

\section{changements côtiers / marais maritime / Holocène / ostracodes / sédiments}

\section{INTRODUCTION}

The Holocene is marked by a global climatic warming inducing a rapid sea-level rise along the world's coastlines Kidson, 1986). Around 6000 years BP, the presentday level was reached and the rate of sea-level rise decreased rapidly CMorzadec-Kerfourn, 1974; Kidson 1986). Holocene sea-level and climate changes are recorded in the sediments of estuarine and coastal marshes which have been investigated all over the world for several years: in Europe (Great Britain: e.g. Allen_2000a Plater et al. 2000, Belgium: e.g. Denis and Baeteman 1995. Baeteman 1999. the Netherlands: e.g. Vos and de Wolf 1997: Berendsen and Stouthamer 2000: Vos and wan Kesteren, 2000. Spain: e.g. Cearreta and_Murray, 1996:Sánchez-Goñi_1996) or along the North Atlantic coast of America (e.g. Duc and Tye, 1987: Jennings et al. 1993; Gehrels, 1994). The rapid deposition rate and a high sensitivity to local environmental changes make the sedimentary archives of the coastal marshes some of the most detailed recordings of coastal changes over the last thousands years.

Along the French Atlantic coastline, relationships between the Holocene sea-level rise and coastal changes have been investigated over 30 years (Verger. 1968. Morzadec-Kerfourn. 1974. 1985: Klingebiel et al. 1980. Regrain. 1980: Clet Pellerin et al. 1981: Sauriau and Gruet, 1988: Visset, 1988; Larsonneur, 1989; Marambat 1992:_Bernard_ 1996.

Recent work on the Holocene evolution of the coastal areas of south-western France (Bay of Biscay) has focused on the marshes of the Gironde estuary (foure Diot and Tastet 1995: Pontee et al. 1998: Mellalieu et bl., 2000; Massé et al. in press a, b, c) and shelf mud patches (Lesueur et al., 1989, 1994, 1996). It is starting to provide a better overall picture of the Holocene infill of the Gironde estuary since 6000 years BP Clavé, 2001
Massé et al., unpubl. results). However, all the investigated areas so far are strongly influenced by the suspended sediments originating from the Garonne and Dordogne rivers. Along the coastline adjacent to the Gironde estuary, the only coastal marshes not under the influence of these suspended sediments are to be found in the north and on the western coast of the Oleron island (Ggure - Our studies were focused on the La Perroche marsh, located on the south-western coastline of this island.

The aim of this work is to reconstruct the Holocene evolution of the La Perroche marsh, in relation with global (e.g. sea-level rise, climate change) and local factors (e.g. sediment inputs). In this marsh, a complete Holocene sequence was sampled (figure - ] $)$ and studied on the basis of sedimentological and microfaunal analyses supported by ${ }^{14} \mathrm{C}$ dating.

\section{REGIONAL SETTING AND PREVIOUS WORK}

The Oleron island (figure 1 ) separates the Bay of Marennes-Oleron from the Atlantic ocean. The Charente and Seudre rivers flow into this bay, largely open to the ocean at its northern exit. To the south, the island is separated from the continent by the Pertuis de Maumusson, a narrow inlet ( $1 \mathrm{~km}$ width, $20 \mathrm{~m}$ depth) with strong tidal currents.

The island consists of Upper Jurassic and Upper Cretaceous limestones and follows the axis of a SE-NW anticlinal (Anticlinal de Gémozac) Bourgeuil et al. 1976. The south-western rocky coast shows several small coastal marshes separated from the ocean by sandy dunes, whereas the north-eastern coast is much more low lying and experiences important sedimentation linked to the suspended sediments of the Charente and Seudre 


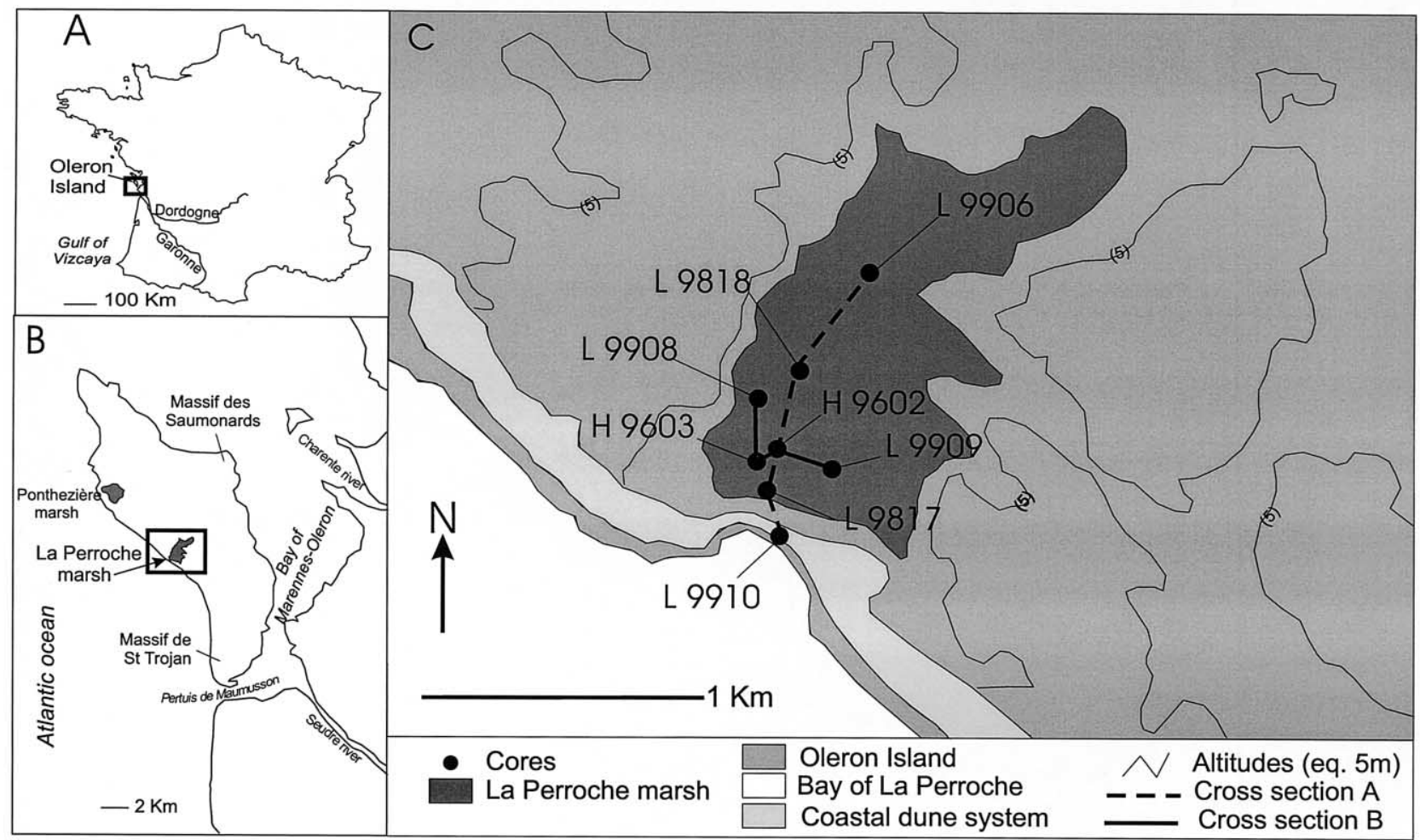

Figure 1. Location map of the Oleron island (A), the La Perroche marsh (B) and the cores inside the marsh (C).

rivers. The entire island is bordered by a coastal dune system which is particularly well developed in the south (Massif de Saint-Trojan), and in the east (Massif des Saumonards).

The shelf of the Bay of Biscay is a meso- to macrotidal (with a period of $12 \mathrm{~h}$ and $25 \mathrm{~min}$ ) and storm wavedominated environment (Pontee et al. 1998). The tidal amplitude reaches $5.5 \mathrm{~m}$ during spring tides CAllen. 1972). The shelf is exposed to westerly storms and large amplitude/long period swells from the west-north-west. Wave heights can reach a maximum of $9 \mathrm{~m}$ but are more frequently around $5 \mathrm{~m}$ with a period range between 8 and $15 \mathrm{~s}$ (Leswewr and Tastet, 1994)

The La Perroche marsh is presently a freshwater swamp separated from the ocean by a continuous sandy dune ridge. The marsh has a surface of $2 \mathrm{~km}^{2}$, a flat top lying around $1 \mathrm{~m}$ NGF ('nivellement général de la France', the French levelling system) and is surrounded by outcrops of Cenomanian limestone, forming the substrate of this part of the island (figure - $)$. Evidences of human occupation dating from the Neolithic age (Artenacian period) were discovered on the south-western margin of the marsh. They consist of building remains, abundant furniture and traces of metallurgic activities Laporte, 1998).

During the last 50 years, Oleron island was mainly investigated from a morphological and lithological point of view (Péchier, 1954; André, 1986) In the vicinity of the La Perroche marsh, palaeoenvironmental investigations were made on a peat layer outcropping on the beach at low tide in front of the small marshes of the southwestern coast (Pineau, 1891; Welsh, 1967). Some cores were studied in 1973 (Gabet_1973), and two samples were dated, indicating a peat development between $4920 \pm 100$ and $3600 \pm 100$ years BP. More recently, Bernard and Gruet (1994) made palynological and malacological investigations in a peat layer from the Ponthezière marsh (figure 1 ) showing the succession, from the base to the top, of marine and terrestrial environments. Around $3410 \pm 60$ years BP, an invasion of freshwater is evidenced. However, these local informations still needed to be improved upon by a complete sedimentological study of the Holocene sequence. 


\section{DATA AND METHODS}

Eight percussion cores (fgure 1 table were collected along two cross-sections running S-N (cross-section A, Goure 2) and NW-W-E (cross-section B, figure 3). All reached the Cenomanian calcareous substrate except one (L 9910) collected on the beach in front of the marsh. The lithology of each core is detailed in Goures 4 and 5 .

Micropalaeontological studies were mainly concentrated on ostracod faunas (figures 2-5). The species were identified, counted, and gathered in four assemblages belonging to two different environments Yassini. 1969. Carbonel.1980:
Table I. Core location (* nivellement général de la France).

\begin{tabular}{lcccc}
\hline Core number & \multicolumn{2}{c}{$\begin{array}{c}\text { Lambert II extended grid } \\
\text { reference }\end{array}$} & $\begin{array}{c}\text { Altitude } \\
\text { NGF* }\end{array}$ & $\begin{array}{c}\text { Length of } \\
\text { the core } \\
(\mathrm{m})\end{array}$ \\
\cline { 2 - 3 } & $x$ & $y$ & $\mathrm{~m})$ \\
\hline H 9602 & 318.280 & 2106.860 & +0.52 & 4.5 \\
H 9603 & 318.205 & 2106.810 & +1 & 3 \\
L 9817 & 318.260 & 2106.680 & +2.086 & 3.7 \\
L 9818 & 318.408 & 2107.240 & +0.8 & 4.3 \\
L 9906 & 318.720 & 2107.710 & +0.85 & 4.2 \\
L 9908 & 318.210 & 2107.110 & +1.17 & 5.1 \\
L 9909 & 318.550 & 2106.760 & +1.02 & 4.1 \\
L 9910 & 318.310 & 2106.450 & +0.13 & 1.1 \\
\hline
\end{tabular}

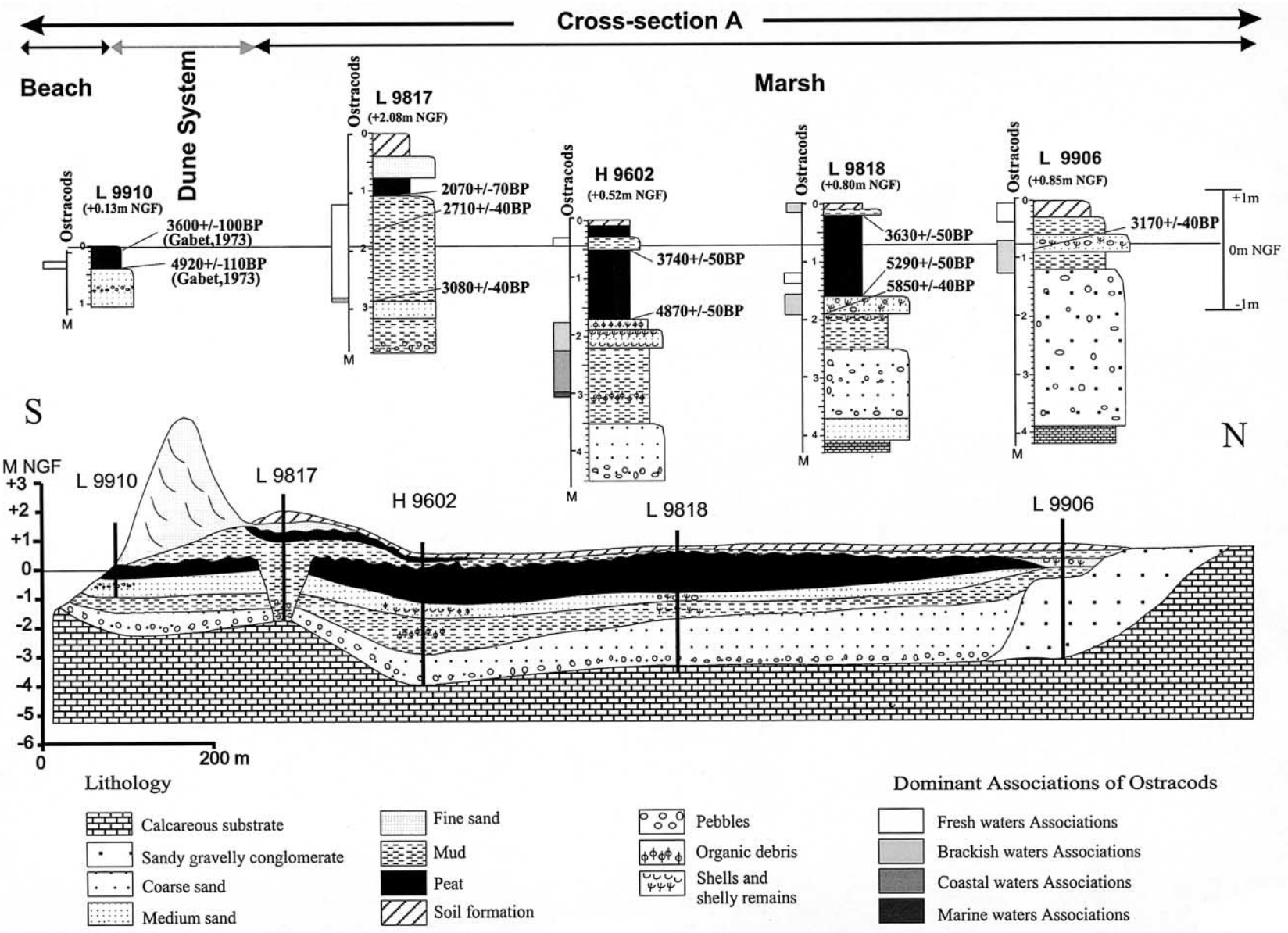

Figure 2. Core lithology and ostracoda fauna distribution along cross-section A. 


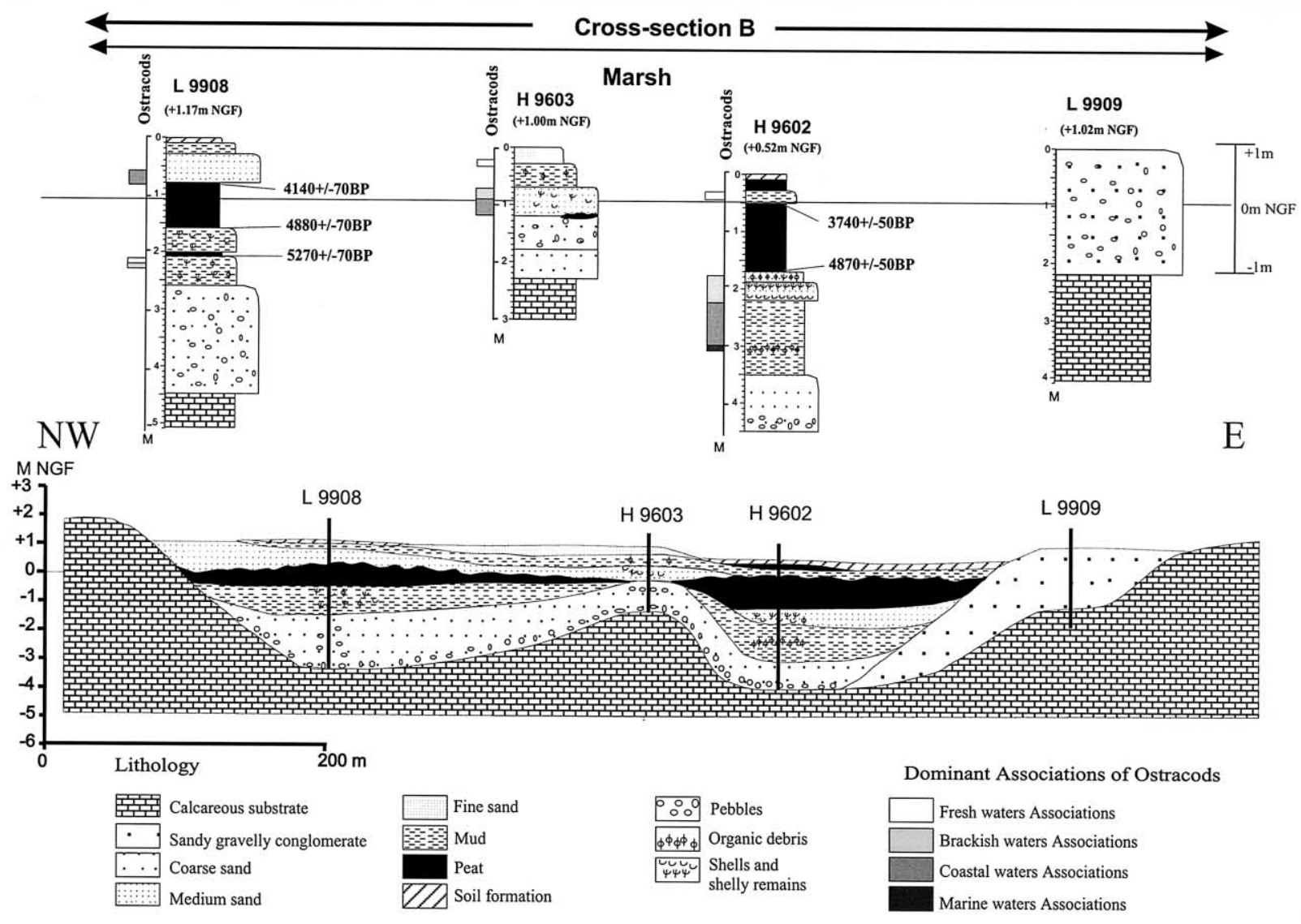

Figure 3. Core lithology and ostarcoda fauna distribution along cross-section B.

- continental (figure 6), with freshwater species (Cypris bispinosa, Ilyocypris gibba, Cypridopsis sp., Cyprinotus sp., Cyclocypris sp., Candona neglecta, Limnocythere inopinata) and brackish water species (Cyprideis torosa, Loxoconcha elliptica);

- marine s.l. (figure 7), with coastal species (Loxoconcha rhomboidea, Leptocythere sp., Aurila convexa, Heterocythereis albomaculata, Urocythereis oblonga, Cushmanidea elongata) and marine s.s. species (Callistocythere sp., Hirschmannia tamarindus, Semicytherura sp. div., Neocytherideis fasciata, Cuneocythere semipunctata, Carinocythereis carinata, Hiltermanicythere emaciata).

Benthic foraminifers were also observed and semiquantitatively estimated. Their occurrence is merely men- tioned and used to estimate the salinity degree. Indeed, the foraminifers do not live in fresh waters.

Charophytes (gyrogonites) were semi-quantitatively estimated. Their occurrence indicates fresh- or brackish water marshes.

Eight conventional and four AMS radiocarbon dates were obtained from peat layers or shell samples (table I l $)$. The latter are corrected for the marine reservoir effect, which has been estimated to be around 400 years (Stuiver and Brazuinas. 1993.

Sedimentation rates (in $\mathrm{cm} \cdot \mathrm{yr}^{-1}$ ) were calculated for the main peat and mud layers. 


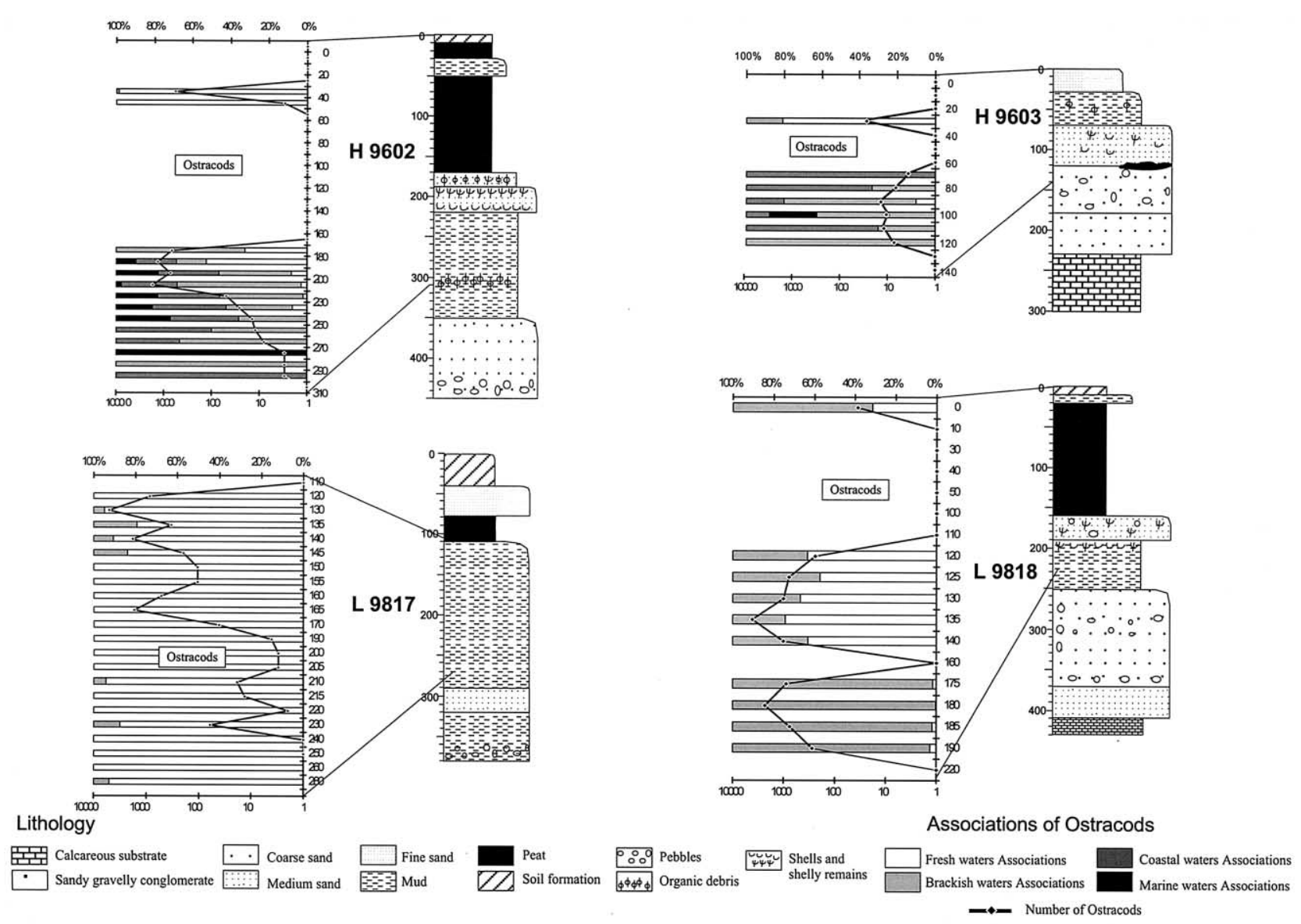

Figure 4. Lithology and ostracoda fauna contents of the cores H 9602, H 9603, L 9817 and L 9818.

\section{RESULTS AND DISCUSSION}

\subsection{The Holocene sequence}

The lithology and faunal content of the cores were used to reconstruct the Holocene sequence of the La Perroche marsh along both cross-sections (figures 2,3).

In its northern (L 9906) and eastern (L 9909) parts, the marsh is occupied by an important basal unit of sand and gravel. It corresponds to the erosion of the calcareous substrate and was previously interpreted as high energy fluvial deposits linked to the last deglaciation CAndré 1986. Given our results, it is impossible to infer an age for these deposits.
Apart from the topmost soil formations, nine main units were distinguished from bottom to top in the Holocene sequence.

1) The base of all cores shows a layer of reworked Cenomanian calcareous substrate, consisting of pebbles and cobbles included in a coarse sandy or gravely matrix.

2) The reworked substrate is topped by a coarse azoic sand with occasional Cenomanian calcareous pebbles at the base. This unit appears to thicken from the south (1 $\mathrm{m}$ in $\mathrm{H}$ 9602) towards the north-west ( $2 \mathrm{~m}$ in L 9908), and may be attributed to the very first Holocene marine invasion in the marsh.

3) A phase of muddy sedimentation follows, with occasional silt laminations, shells and/or plant debris. The maximum sampled thickness of this unit is $1.3 \mathrm{~m}$ in H 9602, where the ostracod faunas consist of polyhaline water species (Loxoconcha rhomboïdea) associated with 


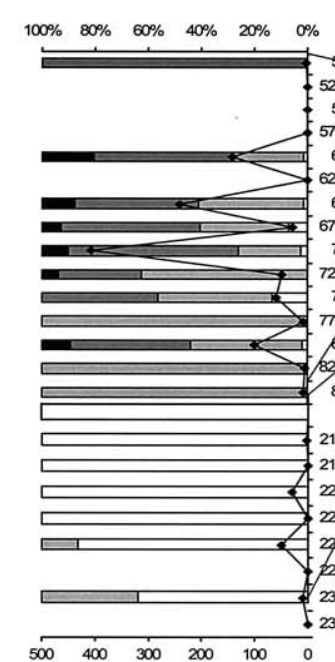

No ostracod fauna
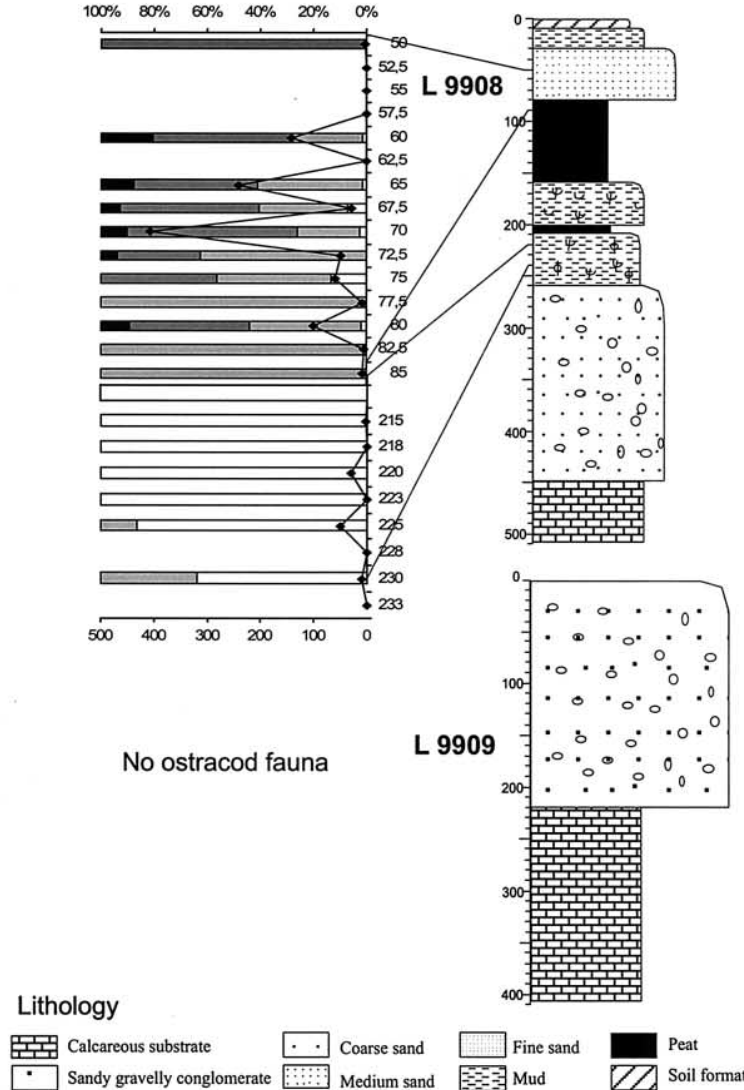

$-\quad$ Sandy gravelly conglomerate Medium sand Fin Mud
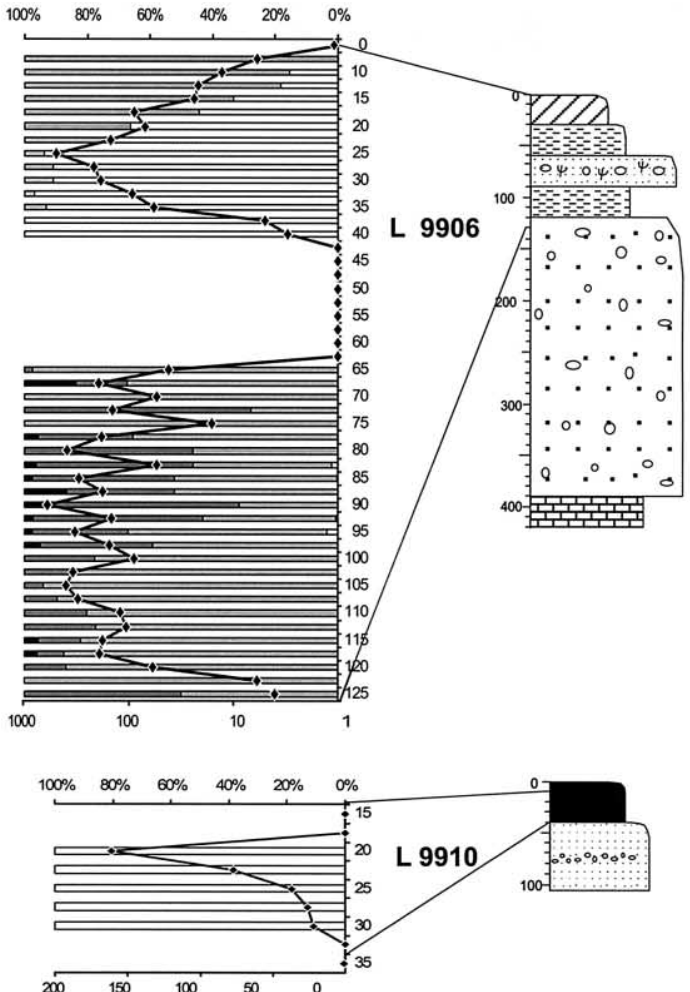

Associations of Ostracods

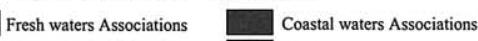
Brackish waters Associations

-־- Number of Ostracods

Figure 5. Lithology and ostracoda fauna contents of the cores L 9908, L 9906, L 9909 and L 9910.

marine species and coastal species (Aurila convexa, Callistocythere sp.). The homogeneous size of all individuals indicates that they were probably transported. To the north-west, core L 9818 shows an abundant ostracod fauna (up to 2300 individuals for $50 \mathrm{~g}$ sediment at $1.8 \mathrm{~m}$ ) at the very top of this unit. It consists mainly of brackish water species, with dominant Cyprideis torosa. Some freshwater organisms as well as charophytes are also present. In core L 9908, the accumulation rate is estimated to be around $0.12 \mathrm{~cm} \cdot \mathrm{yr}^{-1}$. Ostracods appear around $2.3 \mathrm{~m}$ depth and consist of brackish water species progressively replaced by freshwater species until $2.15 \mathrm{~m}$ depth. Their abundance is clearly lower than in L 9918, with a maximum of fifty individuals (for $50 \mathrm{~g}$ sediment) around $2.25 \mathrm{~m}$. This muddy unit indicates a first period of infilling, prior to about 5000 years BP, in a lagoonal/brackish water environment with a well established communication with the sea, allowing marine and coastal species to be transported inside the marsh. Freshwater species are absent, except on the margins of the marsh (L 9908).

4) The mud is topped by a medium sand unit with shell debris, ranging in thickness between $0.7 \mathrm{~m}$ on the beach (L 9910) and $0.5 \mathrm{~m}$ inside the marsh. It contains diverse faunas with a predominance of brackish (Cyprideis torosa and Loxoconcha elliptica) and coastal water species while some marine species subsist. Brackish water faunas are probably in situ as they tend to be complete (juveniles and adults). Numerous foraminifers are observed in this sand, indicating an important reworking of coastal/marine material. Thus, the age of 5850 years BP (corrected from the marine reservoir effect) obtained on shell debris in core L 9818 may be slightly overestimated. The dates obtained on the basal peat directly overlying this unit allow to more confidently estimate the age of its deposition around 5000 years BP. This sand unit indicates a period of stronger dynamic conditions inside the marsh, 


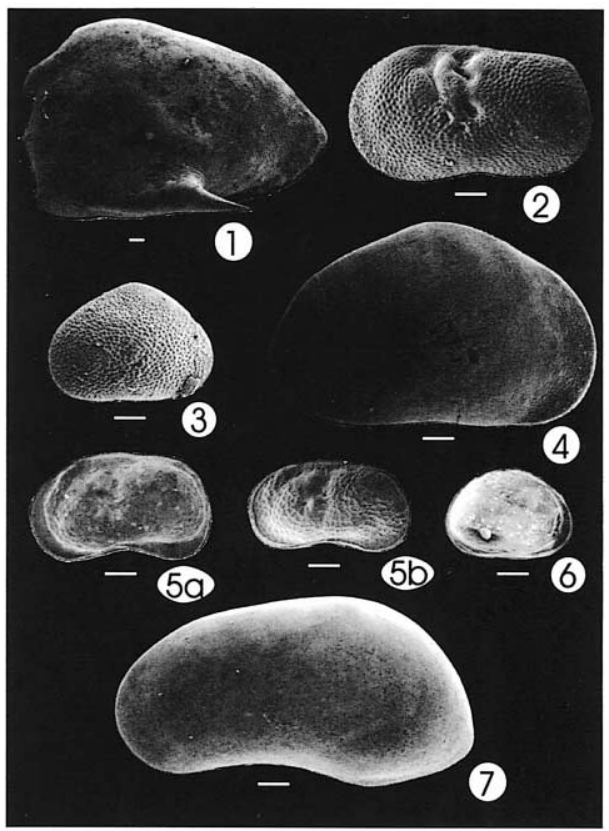

Ostracods of the fresh water Association: (The scale=100 um), 1: Cypris bispinosa; 2: llyocypris sp.; 3: Cypridopsis vidua; 4: Cyprinotus sp.; $5 \mathrm{a}$ and $5 \mathrm{~b}$ : Limnocythere inopinata; 6: Cyclocypris laevis; 7: Candona neglecta

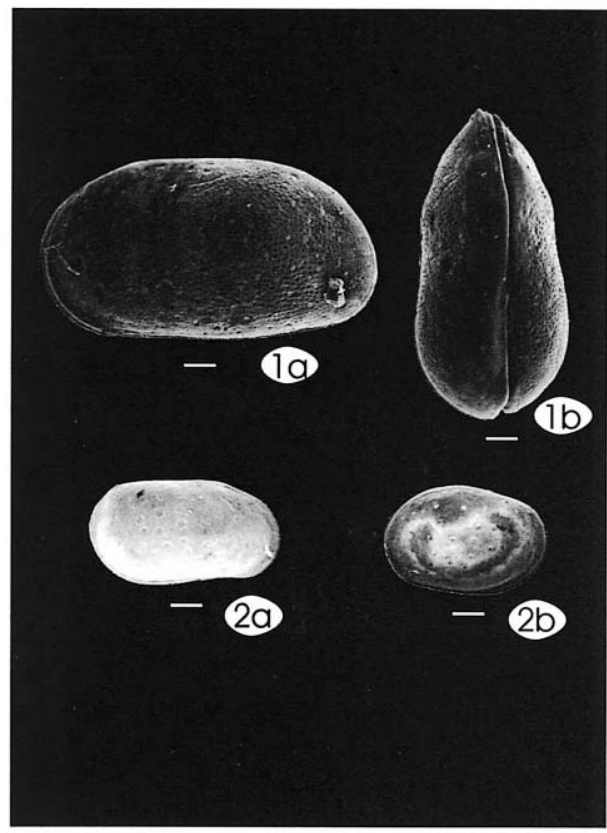

Ostracods of the brackish water Association: (The scale $=100 \mathrm{um}), 1 \mathrm{a}$ and $1 \mathrm{~b}$ : Cyprideis torosa; 2a (male) and 2b (female) :Loxoconcha elliptica

Figure 6. Characteristic ostracods from the freshwater and the brackish water associations.

due to either a positive sea-level tendency or a widening of the communication with the ocean. However, the marsh remains a lagoonal/brackish water environment, as indicated by the continued in situ development of brackish water ostracods.

5) A first peat unit develops, with occasional mud at the base (L 9908, H 9602). This unit appears to be widespread over the marsh and is the one outcropping on the beach at low tide. It indicates either a relative drop in sea level or a reduction of the communication with the sea, resulting in widespread marsh development. The occurrence of this layer on the present-day beach indicates that the coastline was located further to the south-west. The beginning of the peat development is dated between $5270 \pm 70$ (L 9908) and $4870 \pm 50$ years BP (H 9602). The top of this unit shows an abrupt erosive contact with the overlying sand or mud, making it impossible to exactly date its ending; however, the youngest age (3630 \pm 50 years BP in L 9818, which is very close to that of $3600 \pm 100$ years BP obtained on the beach by Gabet, 1973) indicates that peat accumulation in the marsh prevailed during at least 1300 years. The accumulation rate in this peat layer is estimated to be around $0.08 \mathrm{~cm} \cdot \mathrm{yr}^{-1}$.

Peat bogs are characterized by acid waters and usually do not allow the development and/or preservation of calcareous faunas. Inside the present-day marsh, ostracod faunas are restricted to the mud layers found at the base of this unit. They consist of dominant (50 to 70\%) freshwater species (Limnocythere inopinata, Candona sp. in core H 9602; Limnocythere inopinata, Cypridopsis vidua, Candona sp. div. in core L 9908), associated with brackish water species, indicating the persistence of a restricted temporary communication with the sea. Within the peat itself, the only occurrence of ostracod faunas is observed in core L 9818 between 1.2 and $1.4 \mathrm{~m}$ depth, with up to $40 \%$ of brackish water species, indicating the persistence of some form of communication with the sea and in the southernmost core L 9910, with exclusively freshwater species (Candona sp. div., Cypridopsis vidua), indicating this site was not connected to any channel despite being closer to the sea. 


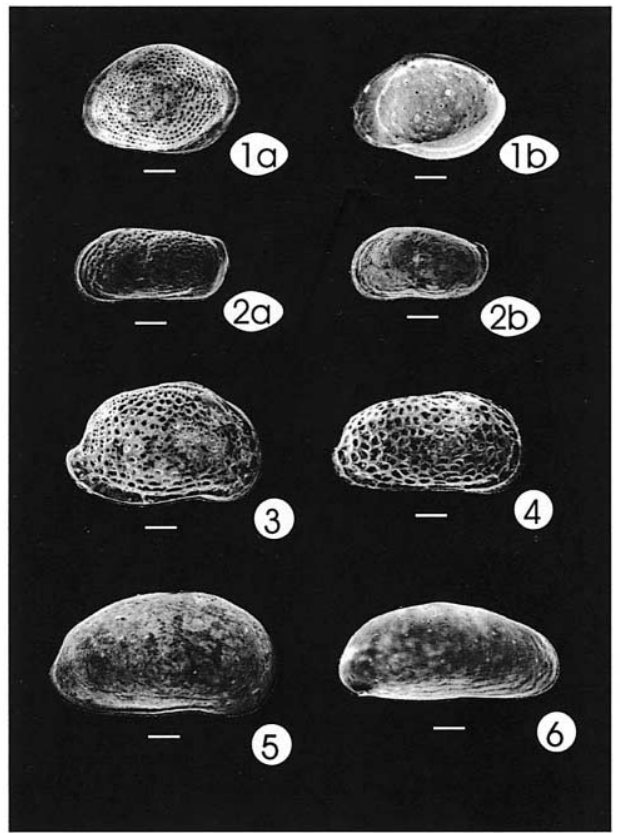

Ostracods of the phytal-coastal Association: (The scale $=100 \mathrm{um}$ ), $1 \mathrm{a}$ and $1 \mathrm{~b}$ : Loxoconcha rhomboidea; 2a and 2b: Leptocythere sp; 3: Aurila convexa; 4: Urocythereis oblonga; 5: Heterocythereis albomaculata;6: Cushmanidea elongata

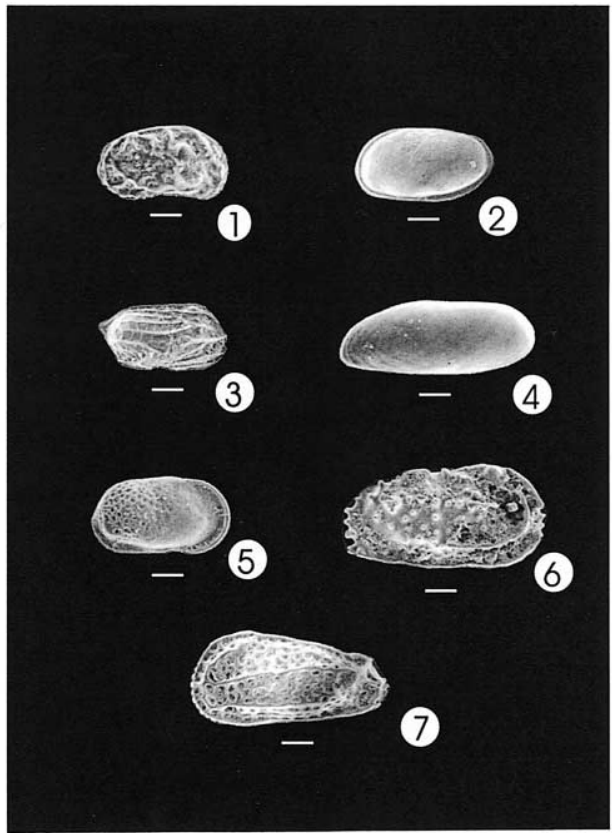

Ostracods of the marine s.I Association: (The scale=100 um),1: Callistocythere sp.; 2: Hirschmannia sp.;3: Semicytherura sp.; 4: Neocytherideis fasciata; 5: Cuneocythere semipunctata; 6: Carinocythereis carinata 7: Hiltermanicythere emaciata

Figure 7. Characteristic ostracods from the phytal-coastal and the marine associations.

Table II. ${ }^{14} \mathrm{C}$ Ages obtained from the La Perroche marsh.

\begin{tabular}{|c|c|c|c|c|c|c|c|}
\hline Core number & $\begin{array}{l}\text { Deph } \\
(\mathrm{cm})\end{array}$ & $\begin{array}{l}\text { Absolute level NGF } \\
\qquad(\mathrm{cm})\end{array}$ & $\begin{array}{c}\text { Age } \\
\text { (years BP) }\end{array}$ & $\begin{array}{l}\text { Calibrated age } \\
\text { (BP) }\end{array}$ & Sample type & Laboratory ref. & Meas. type \\
\hline \multirow[t]{2}{*}{ Н 9602} & 55 & -3 & $3740 \pm 50$ & 2335-1935 ВС & Plant debris & Beta 102691 & Conv \\
\hline & 160 & -108 & $4870 \pm 50$ & 3795-3395 ВС & Plant debris & Beta 102692 & Conv \\
\hline \multirow[t]{3}{*}{ L 9818} & 22 & 58 & $3630 \pm 50$ & $4085-3835 \mathrm{BP}$ & Plant debris & Beta 130951 & Conv \\
\hline & 140 & -60 & $5290 \pm 50$ & $5895-5615 \mathrm{BP}$ & Plant debris & Beta 130950 & Conv \\
\hline & 183 & -103 & $5850 \pm 40$ & $6740-6555 \mathrm{BP}$ & Ostracods & Beta 139287 & AMS \\
\hline \multirow[t]{3}{*}{ L 9908} & 94 & 23 & $4140 \pm 70$ & $4845-4435 \mathrm{BP}$ & Plant debris & Beta 135316 & Conv \\
\hline & 160 & -43 & $4880 \pm 70$ & $5740-5475 \mathrm{BP}$ & Plant debris & Beta 135315 & Conv \\
\hline & 199 & -82 & $5270 \pm 70$ & $6255-5910 \mathrm{BP}$ & Plant debris & Beta 135314 & Conv \\
\hline \multirow[t]{3}{*}{ L 9817} & 110 & 98 & $2070 \pm 70$ & 2300-1875 BP & Plant debris & Beta 130953 & Conv \\
\hline & 165 & 43 & $2710 \pm 40$ & $2870-2755 \mathrm{BP}$ & Ostracods & Beta 139285 & AMS \\
\hline & 290 & -82 & $3080 \pm 40$ & $3375-3210 \mathrm{BP}$ & Shells & Beta 139286 & AMS \\
\hline L 9906 & 97 & -12 & $3170 \pm 40$ & 3465-3340 BP & Ostracods & Beta 139288 & AMS \\
\hline
\end{tabular}

6) The peat is overlain with a sharp boundary by a $0.5-\mathrm{m}$ thick sand layer with occasional shell debris, apparently restricted to the western and northern margins of the marsh (L 9908, H 9603, L 9906). An age of $3170 \pm$
40 years BP (core L 9906) is consistent with the ones obtained from the top of the underlying eroded peat layer, although an eventual reworking and age over-estimation cannot be ruled out. Ostracod faunas show brackish water 
forms progressively replaced by coastal and marine species. The latter are mainly displaced juvenile forms, suggesting they are supplied via a channel communicating with the sea, as presently observed in the Gironde estuary (Carbonel, 1980). The presence of foraminifers in cores H9603 and L 9908 strongly suggests that an effective communication with the sea was re-established.

7) A second mud layer lies above the sand unit on the western and northern margins of the marsh, and directly over the eroded peat bed elsewhere. This mud layer generally does not exceed $0.4 \mathrm{~m}$ in thickness, except at the site of L 9817, where it represents the bottom $3 \mathrm{~m}$ of the core and lies directly above the calcareous substrate. It is therefore inferred that this core represents a deep channel incised in the older deposits at the time of the peat-bog destruction after 3600 years BP (Allen, 2000b Steel and Pye, 1997) The channel was then filled during the deposition of this mud layer. Two ${ }^{14} \mathrm{C}$ dates obtained on shell debris give ages of $3080 \pm 40$ and $2710 \pm 40$ years BP, confirming that this infill is younger than the peat layer. A sedimentation rate of $0.32 \mathrm{~cm} \cdot \mathrm{yr}^{-1}$ demonstrates the rapidity of the channel infilling. Ostracod faunas in core L 9817 are well represented (up to 5000 individuals around $1.3 \mathrm{~m}$ depth) and consist of over $90 \%$ of freshwater species (Cypridopsis vidua, Limocythere inopinata and Candona sp. div.). The other $10 \%$ correspond to brackish water (Loxoconcha elliptica) and coastal (Aurila convexa) forms. Some shell debris are found, along with some foraminifers observed between 2.9 and $1.2 \mathrm{~m}$ depth. In core H 9602, a rich freshwater fauna (Limnocythere and Cypris bispinosa) developed at around $0.4 \mathrm{~m}$ depth in the mud, while core H 9603 shows a brief reappearance of fresh- $(80 \%)$ and brackish water forms $(20 \%)$.

This mud unit indicates a progressive isolation from the ocean and a second phase of terrigenous infilling in mainly freshwater conditions above the erosion surface of the first peat layer. This is consistent with the results obtained by Bernard and Gruet (1994) showing a freshwater invasion after $3410 \pm 60$ years BP in the Ponthezière marsh. Further landward (L 9818, L 9906), the upper mud unit shows quite different faunal associations. In core L 9818, they consist of fresh- (30\%) and brackish water $(70 \%)$ ostracods with foraminifers and charophytes. In core L 9906, ostracods are present between 0.4 and $0.1 \mathrm{~m}$ depth, with exclusively freshwater forms (Candona neglecta, Cypridopsis sp.) at the base, progressively replaced by brackish water species (Cyprideis torosa) above $0.35 \mathrm{~m}$ depth. These characteristics suggest a much better communication with the sea than in the previous sites. Their location further inland suggest they were located closer to a channel communicating with the sea.

8) A second phase of peat development is evidenced in the southern part of the marsh (H 9602, L 9817). This unit does not exceed $0.3 \mathrm{~m}$ in thickness, and its base is dated around $2070 \pm 70$ years BP.

9) A 0.4-m thick sand layer is deposited over this second peat unit (L 9817) or directly above the underlying muds (H 9603). Due to the limited extension of this unit just behind the present-day dune system, it is assumed to represent the landward end of the associated sand sheet.

\subsection{Comparison with the Gironde estuary}

Apart from the sandy-gravely layers covering the substrate, the Holocene sequence of the La Perroche marsh shows a consistent facies alternation which may be interpreted in terms of negative/positive sea-level tendency (Shennan et al, 1983).

After the first phase of mud deposition, a sand layer with reworked marine faunas is observed throughout the marsh. It is dated between 5850 (reworked marine shells) and $5290 \pm 50$ years BP (overlying peat) and indicates either a rising sea level or increased storminess. As there is no contemporaneous evidence of a similar event, either in the Gironde estuary or along the Aquitaine coast, we assume that the deposition of this sand layer is the result of a local influence (i.e. a positive sea-level tendency, a storm event).

The first phase of peat development may be interpreted as the result of a high water table and stable sea-level around 5300-4900 years BP. Similar peat layers developed at around the same time or slightly earlier in the internal/median zones of the Gironde estuary (5600 5000 years BP on the east bank, Mellaliew et al. 2000. 6200-5700 years BP on the west bank, Massé et al., in press $b$ ). These peat beds did not extend towards the estuary mouth due to a slower deposition rate/deeper substrate at that time (Massé et al._in press c).

The top of the peat bed is eroded and overlain on the eastern margin of the marsh by a sand layer containing reworked marine shells dated 3170 years BP, once again indicating a positive sea-level tendency or increased storminess. The exact age of this event, which might 
have happened over a long time span, is difficult to assess as the top of the peat is eroded and the dated shells are most probably reworked. It occurs sometime between 3600 (the youngest date at the top of the first peat layer) and 2100 years BP (the beginning of the second period of peat development). However, there are numerous evidences for a similar and contemporaneous event throughout the Gironde estuary deposits. In the internal/median parts, a widespread erosion phase of the peat followed by a return to muddy deposition is evidenced on the east bank; it is even more difficult to date than in La Perroche but occurs before 2100 years BP (Mellalieu et al. 2000). Closer to the estuary mouth, a 'transgressive' event is inferred from benthic foraminifer distribution in the muddy infill of the east bank around 2800 years BP Massé et al, in press c), while a $25-\mathrm{km}$ long and up to 5-m thick chenier ridge (Cordon de Richard) developed on the west bank between 3000-2400 years BP (Massé ed bl, in press all This event is apparently not restricted to the French Atlantic coast. Numerous palaeoenvironmental studies highlight an episode of positive sea-level tendency between 3000 and 2000 years BP along the Atlantic north-western European coastlines Clavé et_al In prep from the North Sea and the British Isles (e.g. Baeteman, 1999: Berendsen and Stouthamer, 2000: Brew et al 2000; Metcalfe et al, 2000; Plater et al, 2000a $2000 \mathrm{~b}$ to the Spanish Cantabrian peninsula (e.g. Cear eta, 1993, 1994; Sánchez Goñi, 1996) This event may reflect an episode of rising sea level CClemmensen et al. 1996; Long et al, 1999) and/or an increase in storminess and water precipitations leading to marshland inundations Visset 1988: Regnauldetal. 1996: Spencer et al_ 1998. Waller et al. 1999; Brew et al.,2000). Some authors refer to a shift to wetter climatic conditions throughout northwestern Europe around the subboreal/subatlantic transition Van Geel et al., 1996; Anderson et al. 1998)

The second phase of peat development after 2100 years BP may indicate a new episode of stable or negative sea-level tendency. It is then interrupted by the settling of the present-day dune system and associated sand sheet.

\section{SUMMARY AND CONCLUSIONS}

This study allows the complete reconstruction of the Holocene sequence of the La Perroche marsh infilling, which can be summarized in six steps:

- During the Last Glacial Event (sea-level fall and lowstand), the calcareous substrate was eroded and a fluvial sandy-gravely unit was deposited. It is particularly thick on the northern and eastern margins of the marsh, preventing these areas from further accumulation.

- Around 6000 years BP, the La Perroche depression was flooded by the sea. Poorly-sorted gravely, sandy to muddy clastic deposits containing brackish water and reworked coastal ostracods accumulate over the whole marsh, probably looking like a brackish water lagoon with restricted but perennial communication with the sea. Tidal currents reach the northern part of the depression. A first phase of mud deposition follows with a sedimentation rate of $0.12 \mathrm{~cm} \cdot \mathrm{yr}^{-1}$ (core L 9908).

- An episode of marine invasion between 5800 and 5300 years BP results in a brief return to sand deposition with reworked marine shells and ostracod faunas.

- After 5300-4900 years BP, the communication with the sea decreases. A peat layer develops over the whole marsh (with an average sedimentation rate of $0.1 \mathrm{~cm} \cdot \mathrm{yr}^{-1}$ ), while ostracod faunas rapidly disappear after a brief episode of freshwater species development. - Sometime between 3600 and 2100 years BP, and probably around 3000 years BP, a transgressive event causes a new flooding of La Perroche, resulting in the erosion of the upper part of the peat layer and the deposition of coastal and freshwater muds. This event is evidenced elsewhere in the Gironde estuary as well as in numerous locations in north-western Europe, demonstrating an episode of rising sea level/increased storminess/high atmospheric humidity between 3000 and 2000 years BP. - A second phase of peat development occurs after 2100 years BP, indicating the definitive closing of the marsh. After that date, the La Perroche site is occupied by a freshwater marsh isolated from the ocean by the settling of the present-day sand dune system. A sporadic or highly channelized communication with the sea may occur as indicated by occasional brackish water ostracods in the deposits.

\section{Acknowledgements}

This work was realized in the framework of the European LIFE programme 'Coastal Change, Climate and Instability' (97ENV/UK/000510) coordinated by the County Council of the Isle of Wight. The authors would like to thank especially Mrs Cécile Baeteman and M Pierre Giresse for their invaluable help in improving the manuscript. This work is UMR 5805 EPOC contribution No. 1358. 


\section{REFERENCES}

Allen, G.P., 1972. Études processus sédimentaires dans l'estuaire de la Gironde. Ph.D. thesis, université Bordeaux-I, No. 379.

Allen, J.R.L., 2000a. Late Flandrian (Holocene) tidal paleochannels, Gwent Levels (Severn Estuary), SW Britain: character, evolution and relation to shore. Mar. Geol. 162, 353-380.

Allen, J.R.L., 2000b. Morphodynamics of Holocene salt marshes: a review sketch from the Atlantic and Southern North Sea coasts of Europe. Quat. Sci. Rev. 19, 1115-1231.

Anderson, D.E., Binney, H.A., Smith, M.A., 1998. Evidence for abrupt climatic change in northern Scotland between 3900 and 3500 calendar years BP. The Holocene 8, 97-103.

André, A., 1986. Élaboration et analyse de cartes bathymétriques détaillées du proche plateau vendéo-charentais (Golfe de Gascogne). Ph.D. thesis, université Bordeaux-I, No. 2133.

Baeteman, C., 1999. The Holocene depositional history of the Ijzer palaeovalley (western Belgian coastal plain) with reference to the factors controlling the formation of intercalated peat beds. Geol. Belg. 2/3, 4, 39-72.

Berendsen, H.J.A., Stouthamer, E., 2000. Late Weichselian and Holocene palaeogeography of the Rhine-Meuse delta, The Netherlands. Palaeogeogr. Palaeoclimatol. Palaeoecol. 161, 311-335.

Bernard, J., 1996. Paléoenvironnement du Pays-de-Retz et du marais breton-vendéen. Ph.D. thesis, université de Nantes.

Bernard, J., Gruet, Y., 1994. Analyse pollinique et malacologique de la tourbe de Ponthezière, Ile d'Oléron (Saint-Georges-d'Oléron, Charente Maritime). Bull. Soc. Sc. Nat. Ouest France, nouvelle série 16, 1-9.

Bourgueil, B., Moreau, P., Dubreuilh, J., 1976. Carte géol. France (1/50 000), Feuille Ile d'Oléron (657), Orléans: BRGM (Notice explicative par Bourgueil, B., Moreau, P., Dubreuilh, J., Vouvé, J., 1976).

Brew, D.S., Holt, T., Pye, K., Newsham, R., 2000. Holocene sedimentary evolution and palaeocoastlines of the Fenland embayment, eastern England. In: Shennan, I., Andrews, J. (Eds.), Holocene Land-Ocean Interaction and Environmental Change around the North Sea, Geological Society, London, Special Publications, 166, pp. 197-217.

Carbonel, P., 1980. Les Ostracodes et leur intérêt dans la définition des écosystèmes estuariens et de la plate-forme continentale. Essais d'application à des domaines anciens. Mémoires de l'Institut de Géologie du Bassin d'Aquitaine, vol. 11.

Cearreta, A., 1993. Palaeoenvironmental interpretation of Holocene coastal sequences in the southern Bay of Biscay. Geol. Rundsch. 82, 234-240.

Cearreta, A., 1994. Analisis micropaleontológico e interpretación paleoecologica del relleno sedimentario holoceno en el estuario del bidasoa (golfo de Bizkaia). Geobios 27, 271-283.

Cearreta, A., Murray, J.W., 1996. Holocene palaeoenvironmental and relative sea-level changes in the Santona Estuary, Spain. J. Foraminiferal Res. 26, 289-299.

Clavé, B., 2001. Changements côtiers à l'Holocène en zone aquitaine et saintongeaise. Mémoire de doctorat, université Bordeaux-I.
Clavé, B., Massé, L., Diot, M.F., Carbonel, P., Tastet, J.P. Palaeoenvironmental and archaeological evidences of an abrupt climatic change along the French southwestern coasts between 3000 and 2000 years BP, in prep.

Clemmensen, L.B., Andreasen, F., Nielsen, S., Sten, E., 1996. The late Holocene coastal dune-field at Vejers, Denmark: characteristics, sand budget and depositional dynamics. Geomorphology 17, 79-98.

Clet-Pellerin, M., Lautridou, J.P., Delibrias, G., 1981. Les formations holocènes et pléistocènes de la partie orientale de la Baie du Mont Saint-Michel. Bull. Soc. Limn. Normandie 109, 3-20.

Denys, L., Baeteman, C., 1995. Holocene evolution of relative sea level and local mean high water spring tides in Belgium - a first assessment. Mar. Geol. 124, 1-19.

Diot, M.F., Tastet, J.P., 1995. Paleo-environnements holocènes et limites chronoclimatiques enregistrés dans un marais estuarien de la Gironde (France). Quaternaire 6, 85-94.

Duc, A.W., Tye, R.S., 1987. Evolution and stratigraphy of a regressive barrier/backbarrier complex: Kiawah Island, South Carolina. Sedimentology 34, 237-251.

Gabet, C., 1973. Le banc de tourbe sur l'estran de la baie de Perroche (Île d'Oléron). Bull. Soc. Archéol. Hist. Charente Maritime 25, 297-307.

Gehrels, W.R., 1994. Determining relative sea-level change from salt-marsh foraminifera and plant zones on the coast of Maine. USA. J. Coastal Res. 10, 990-1009.

Jennings, S.C., Carter, R.W.G., Orford, J.D., 1993. Late Holocene salt marsh development under a regime of rapid-sea-level rise: Chezzetcook Inlet, Nova Scotia. Implications for the interpretation of palaeomarsh sequences. Can. J. Earth Sci. 30, 1374-1384.

Kidson, C., 1986. Sea-level changes in the Holocene. In: Van de Plaasche, O. (Ed.), Sea-Level Research: A Manual for the Collection and the Evaluation of the Data. Geo Books, Norwich, pp. 27-64.

Klingebiel, A., Larsonneur, C., Castaing, P., Pujos, M., Barbaroux, L., Gouleau, D., Ottoman, F., Avoine, J., Dupont, J., Hommeril, P., 1980. Modèle de sédimentation littorale actuelle en zone tempérée. La façade maritime française de l'Atlantique à la Manche. Bull. Inst. Géol. Bassin Aquitaine 27, 113-164.

Laporte, L., Cros, J.-P., Fontugne, M., Gebhardt, A., Gruet, Y., Marguerite, D., Oberlin, C., 1998. Les occupations néolithiques de la côte occidentale de l'île d'Oléron, L'Homme préhistorique et la mer, $120^{\mathrm{e}}$ Congrès CTHS, Aix-en-Provence, pp. 197-238.

Larsonneur, C., 1989. La baie du Mont-Saint-Michel: Un modèle de sédimentation en zone tempérée. Bull. Inst. Géol. Bassin Aquitaine $46,5-73$.

Lesueur, P., Tastet, J.P., 1994. Facies, internal structures and sequences of modern Gironde-derived muds on the Aquitaine inner shelf, France. Mar. Geol. 120, 267-290.

Lesueur, P., Weber, O., Marambat, L., Tastet, J.P., Jouanneau, J.M., Turon, J.L., 1989. Datation d'une vasière de plate-forme atlantique au débouché d'un estuaire : la vasière à l'ouest de la Gironde (France) est d'âge historique (VI ${ }^{\mathrm{e}}$ siècle à nos jours). C. R. Acad. Sci. Sér. II 308, 935-940. 
Lesueur, P., Tastet, J.P., Marambat, L., 1996. Shelf mud fields formation within historical times: examples from offshore the Gironde estuary, France. Cont. Shelf Res. 16, 1849-1870.

Long, A.J., Scaife, R.G., Edwards, R.J., 1999. Pine pollen in intertidal sediments from Poole Harbour, UK; implications for late-Holocene sediment accretion rates and sea-level rise. Quat. Int. 55, 3-16.

Marambat, L., 1992. Paléoenvironnements et empreinte anthropique dans l'Ouest Aquitain et la Saintonge à l'Holocène. L'apport de la palynologie. Ph.D. thesis, université Bordeaux-I.

Massé, L., Clavé, B., Tastet, J.P., Gruet, Y., in press a. The 'Cordon de Richard': morphology and construction processes of a fossil chenier ridge on the western bank of the Gironde estuary, S.W. France. Quat. Int.

Massé, L., Diot, M.F., Tastet, J.P., Capdeville, J.P., Lapeyre, R., Marambat, L., Lesueur, P., in press b. Holocene palaeoenvironments of the Reysson marsh on the western bank of the Gironde estuary, S.W. France. Quat. Int.

Massé, L., Wang, J., Tastet, J.P., in press c. Vertical accretion of the Holocene infill of the Monards marsh (Barzan, Gironde Estuary, France). Quat. Int.

Mellalieu, S.J., Massé, L., Coquillas, D., Alfonso, S., Tastet, J.P., 2000. Holocene development of the east bank of the Gironde estuary: geoarchaeological investigation of the Saint-Ciers-sur-Gironde marsh. In: Pye, K., Allen, J.R.L. (Eds.), Coastal and Estuarine Environments: Sedimentology, Geomorphology and Geoarcheology. Geological Society, London, Special Publications, 175, pp. 317-341.

Metcalfe, S.E., Ellis, S., Horton, B.P., Innes, J.B., McArthur, J., Mitlehner, A., Parkes, A., Pethick, J.S., Rees, J., Ridgway, J., Rutherford, M.M., Shennan, I., Tooley, M.J., 2000. The Holocene evolution of the Humber Estuary: reconstructing change in a dynamic environment. In: Shennan, I., Andrews, J. (Eds.), Holocene Land-Ocean Interaction and Environmental Change around the North Sea. Geological Society, London, Special Publications, 166, pp. 197-217.

Morzadec-Kerfourn, M.T., 1974. Variations de la ligne de rivage armoricaine au Quaternaire. Analyse pollinique de dépôts organiques littoraux. Mém. Soc. Géol. Minéral. Bretagne vol. 17.

Morzadec-Kerfourn, M.T., 1985. Variations du niveau marin à l'Holocène en Bretagne (France). Eiszeitalter Gegenwart Hannover $35,15-22$.

Péchier, M., 1954. Géologie de l'Ile d'Oléron. D.E.S., université Bordeaux-I.

Pineau, E., 1891. Nouvelle contribution à la géographie préhistorique des côtes occidentales de France, Association Française pour l'Avancement des Sciences, Congrès de Marseille, p. 206.

Plater, A.J., Horton, B.P., Hayworth, E.Y., Appleby, P.G., Zong, Y., Wright, M.R., Rutherford, M.M., 2000a. Holocene tidal levels and sedimentation rates using a diatom-based palaeoenvironmental reconstruction: the Tees estuary, northeastern England. The Holocene 10, 441-452.

Plater, A.J., Ridgway, J., Rayner, B., Shennan, I., Horton, B.P., Hayworth, E.Y., Wright, M.R., Rutherford, M.M., Wintle, A.G., 2000b. Sediment provenance and flux in the Tees Estuary: the record from the Late Devensian to the present. In: Shennan, I.,
Andrews, J. (Eds.), Holocene Land-Ocean Interaction and Environmental Change around the North Sea. Geological Society, London, Special Publications 166, pp. 197-217.

Pontee, N.I., Tastet, J.P., Massé, L., 1998. Morphosedimentary evidence of Holocene coastal changes near the mouth of the Gironde and on the Medoc peninsula, SW France. Oceanol. Acta 21, 243-261.

Regnauld, H., Jennings, S., Delaney, C., Lemasson, L., 1996. Holocene sea-level variations and geomorphological response: an example from northern Brittany (France). Quat. Sci. Rev. 15, 781-787.

Regrain, R., 1980. Géographie physique et télédétection des marais charentais. Thèse d'État, univ. Bretagne-Occidentale, Brest.

Sánchez-Goñi, M.F., 1996. Vegetation and sea-level changes during the holocene in the estuary of the Bidasoa. Quaternaire 7, 207-219.

Sauriau, P.G., Gruet, Y., 1988. Essai de reconstitution d'un paléoenvironnement marin récent dans le marais poitevin (Charente maritime). Haliotis 18, 9-20.

Shennan, I., Tooley, M.J., Davis, M.J., Haggart, B.A., 1983. Analysis and interpretation of Holocene sea-level data. Nature 302, 404-406.

Spencer, C.D., Plater, A.J., Long, A.J., 1998. Rapid coastal change during the mid- to late Holocene: the record of barrier estuary sedimentation in the Romney Marsh region, southeast England. The Holocene 8, 143-163.

Steel, T.J., Pye, K., 1997. The development of saltmarsh tidal creek networks: evidence from the UK. Canadian Coastal Conference.

Stuiver, M., Brazuinas, T.F., 1993. Modeling atmospheric ${ }^{14} \mathrm{C}$ influences and ${ }^{14} \mathrm{C}$ ages of marine samples back to $10,000 \mathrm{BC}$. Radiocarbon 35, 137-189.

Van Geel, B., Buurman, J., Waterbolk, H.T., 1996. Archaeological and palaeoecological indications of an abrupt climate change in The Nederlands, and evidence for climatological teleconnections around 2650 BP. J. Quat. Sci. 11, 451-460.

Verger, F., 1968. Marais et Waddens du littoral français. Biscaye Frères, Bordeaux.

Visset, L., 1988. The Bière marshlands: a palynological survey. New Phytol. 110, 409-424.

Vos, P.C., de Wolf, H., 1997. Palaeo-environmental diatom study of the Holocene deposits of the Province of Zeeland (SW Netherlands. Meded. Ned. Inst. Toegep. Geowet. TNO 59, 111-141.

Vos, P.C., Van Kesteren, W.P., 2000. The long-term evolution of the intertidal mudflats in the northern Netherlands during the Holocene; natural and anthropogenic processes. Cont. Shelf Res. 20, $1687-1710$.

Waller, M.P., Long, A.J., Long, D., Innes, J.B., 1999. Patterns and processes in the development of coastal mire vegetation: Multi-site investigations from Walland Marsh, Southeast England. Quat. Sci. Rev. 18, 1419-1444.

Welsh, J., 1967. Les lignites du littoral et les forêts submergées de l'Ouest de la France. Anthropologie 23, 201-223.

Yassini, I., 1969. Écologie des associations d'Ostracodes du Bassin d'Arcachon et du littoral atlantique : application à l'interprétation de quelques populations du Tertiaire aquitain. Bull. Inst. Géol. Bassin d'Aquitaine 7, 288. 